\title{
TO COPY OR TO LEARN FROM THE PAST? A RESEARCH PATH FOR A CRITIQUE OF THE NEO- MEDIEVAL APPROACH TO THE REGULATION OF NEW TECHNOLOGIES
}

\author{
Francesco Cirillo, PhD Candidate \\ University of Roma "Niccolò Cusano", "Law and Cognitive Neuroscience" \\ Via Don Carlo Gnocchi, 3, Rome, Italy \\ francesco.cirillo@unicusano.it
}

\begin{abstract}
A part of the literature considers the collapse of the legal categories of modernity as an opportunity for the recovery of concepts of medieval juridical experience. The evidence for such approach includes the following: the variable geometry of the legal sources, the diversification between the recipients of the norms, the collapse of bourgeois property and the substitution with a multilevel order, the overcoming of the state and the definition of a new society in which power is managed by different centers of production of law, the return of the lex mercatoria, the soft law and the ius commune. This paper contributes by reviewing some of the main positions and analyzing the reasons for this possible recovery. Then, such approach will be criticized highlighting that, from a theoretical-general perspective, the technological landscape does not allow a naïve recovery of the past. Rather than copying from the past and imagining impossible continuities, the relationship between technology and humanities points to a different path. In this path, historical methodology could be useful for the law of new technologies, allowing us to distance ourselves from present legal and political concepts and to adopt new ones.
\end{abstract}

Keywords: humanities, new technologies, legal theory, legal history, constitutional law, European law, constitutionalism, legal concepts 


\section{INTRODUCTION}

\subsection{The general question}

«Dieses also ist die allgemeine Frage: in welchem Verhältniß steht die Vergangenheit zur Gegenwart oder das Werden zum Seyn?» ${ }^{1}$ With this question, in 1815, F. C. von Savigny opened his manifesto of the Historische Rechtschule, dedicated to the purpose of the new founded review, the Zeitschrift für geschichtliche Rechtswissenschaft. $^{2}$

In the manifesto, the author divided the world of culture into two opposite factions. The first, the historical one, in which history was not to be considered only a «Beyspielsammlung, sondern der einzige Weg zur wahren Erkenntiß unsers eigene Zustandes». ${ }^{3}$ The second, the non-historical or philosophical one, which considered the future as a world detached from the present and the past, with a naïve hope of designing a rational world.

The historical challenge between the Enlightenment thought and the historical School is still considered open. ${ }^{4}$ The dark relationship between Werden and Sein, between continuity and fracture, is repeated in the regulation of the new technological landscape. One question arising from this new declination is: do new technologies require new legal concepts or, maybe, are the answers from the past sufficient? ${ }^{5}$

A first path seems to follow a tricky route. It is clear that the categories of modernity are in crisis; ${ }^{6}$ then, a revival of the previous concepts seems possible. If the

1 «So this is the general question: what is the relationship between past and present or between becoming and being?»" (our translation), this quotation is from von Savigny, F. C., Über Den Zweck dieser Zeitschrift, Zeitschrift für geschichtliche Rechtswissenschaft, no. 1, 1815, pp. 1-18; here, pp. 2-3

2 On this manifesto see, among others, Rückert, J., Savigny Studien, Klostermann, Frankfurt am Main, 2011, or Id. (ed.), Idealismus, Jurisprudenz und Politik bei Friedrich Carl von Savigny, Klostermann, Frankfurt am Main, 2019

3 Savigny, op. cit. note 1, p. 4: «not an example collection, but the only way to the true knowledge of our own condition».

4 On the School, see the recent study of Haferkamp, H.-P., Die Historische Rechtsschule, Klostermann, Frankfurt am Main, 2018

5 In the Italian literature, for example and overall, Irti, N., Un diritto incalcolabile, Giappichelli, Torino, 2016

6 The crisis of the legal and political concept is observed by several scholars; in Italian constitutional legal doctrine see Luciani, M., L'antisovrano e la crisi delle costituzioni, Rivista di diritto costituzionale, no. 1, 1996, pp. 164-65; in the legal philosophical field, see also Preterossi, G., Tramonto del diritto moderno?, in: Bazzicalupo, L.; Esposito, R. (eds.), Politica della vita. Sovranità, biopotere, diritti, Laterza, Roma-Bari, 2003, pp. 43-48 
pars destruens of this topic seems to be right, maybe the pars construens can hide a paralogism.

In this view, modernity appears like a bubble in the history of humanity. Once this bubble has burst, with its ambitions and its pretensions, the future would appear as the return to a sort of disordered Middle Ages, in which the modern absolute concepts do not exist. In this landscape, constitutionalism dissolves, leaving room for a new "glocal" balance, a tension between global empire and small counties, typical of some static and illusory images of the Middle Ages that moderns have built. $^{7}$

In this contribution we are dealing with a contemporary general theoretical approach to new technologies, underlining the attempts to recover solutions from the past. We analyze some of the appeals to "neo-medieval" legal concepts as an alternative to the modern legal concepts that appear to be in crisis. Nevertheless, the overall framework of references to the entanglement and multi-normativity in legal history allows for deconstructing some current assumptions of "positive jurists".

First, we will focus on the clichés of the appeal to history in contemporary law. Then, we will underline the profiles of the categories adopted, highlighting some naivety, as the static image offered by the lex mercatoria and the ius commune. Such an appeal to the past may flatten the historical reflection, because of the use of abstract and static concepts and historical misconceptions. The latter methodological approach also tends to simplify the view of the present.

The regulation of the technological landscape often uses premodern concepts, if not medieval ones, because of the inadequacy and the uselessness of modern legal models.

However, the legal history, rather than appearing as a reservoir of positive solutions, from the methodological point of view and in the approach to the issue of multi-normativity and entanglement in legal history, allows the jurist to detach himself from the dogmatic and static legal concepts.

Gamble, A., Regional Blocs, World Order and the New Medievalism, in: Telov, M. (ed.), European Union and New Regionalism, Ashgate, Aldershot, 2001, pp. 30-31 and Friedrichs, J., The Meaning of New Medievalism, European Journal of International Relations, no. VII, 2001, pp. 483-486; see also Kobrin, S. J., Neomedievalism and the Postmodern Digital World Economy, in: Prakash, A.; Hart, J. A. (eds.), Globalization and Governance, Routledge, London, 1999, p. 167 ff. 
History allows us to distance ourselves from the present, just as the historian does with the past. This effort could lead us to gain a scientific and methodologically founded perspective on the regulation of new technologies.

The direction allows, finally, for us to undertake a hard but mandatory path to rethink legal concepts, with special reference to the framework of constitutionalism and the challenges of the technological landscape.

\subsection{The state of art}

A part of the literature considers the collapse of the modern legal concepts as an opportunity to recover concepts of medieval law but, from a historical point of view, several criticisms come to light. ${ }^{8}$

The concepts suitable for recovery are the following: the variable geometry of the legal sources, ${ }^{9}$ the diversification between the recipients of the norms, ${ }^{10}$ the collapse of bourgeois property and the substitution with a multilevel order, ${ }^{11}$ the overcoming of the state ${ }^{12}$ and the definition of a new society in which power is managed by different centers of production of law, the return of the lex mercatoria, ${ }^{13}$

8 One of the best and most remarkable examples of this approach is maybe in Grossi, P., Unità giuridica europea: un medioevo prossimo futuro?, Quaderni fiorentini, no. 31, 2002, pp. 39-57, in the same volume, see also the contributions of Costa, P.; Ferrarese, M. R.; Padoa Schioppa, A.; D'Andrea, D.; Duso, G.; Cassese, S.; Malandrino, C.; Cannizzaro, E; Fioravanti, M.; De Benedictis, A.; Castiglione, D.; Berti, G. and Mattei, U.; the reference to the "overcoming Middle Ages" is commonly linked to a well-known Italian futurology book, Vacca, R., Il medioevo prossimo venturo, Mondadori, Milano, 1973

9 On this new geometry, see overall Teubner, G., Constitutional Fragments: Societal Constitutionalism and Globalization, OUP, Oxford, 2012, pp. 1-14

10 The crisis of concept of citizenship is also observed by Costa, P., Cittadinanza, Laterza, Roma-Bari, 2014; see also Habermas, J., Citizenship and National Identity: Some Reflections on the Future of Europe, Praxis International, no. 12, 1992, pp. 1-19

11 On the modern concept of property, see diffusely Grossi, P., La proprietà e le proprietà nell'officina dello storico, Editoriale Scientifica, Napoli, 2006

12 This subject is deeply developed in Italian doctrine also by Cassese, S., La crisi dello stato, Laterza, Roma-Bari, 2002

13 About the history of commercial law and the myth of lex mercatoria, see also Petit, C., Historia del derecho mercantile, Marcial Pons, Madrid, 2016, pp. 33-37; diffusely in Piergiovanni, V. (ed.), From Lex Mercatoria to Commercial Law, Duncker \& Humblot, Berlin, 2005; on the new lex mercatoria, Berger, K. P., The Creeping Codification of the New Lex Mercatoria, Kluwer, Köln, 2010, pp. 1-18, or diffusely in Galgano, F., Lex mercatoria, Il Mulino, Bologna, 2001 
the soft law ${ }^{14}$ and even the ius commune with its usus modernus (or hodiernus). ${ }^{15}$ In this framework, the neo-medieval taste also encompasses a sort of neoclassicism, attempting to recover the tradition of Roman law, if not of a proper form of new Pandektistik. ${ }^{16}$

\subsection{The starting point of the research}

The paper aims to resume the main positions and analyze the reasons for this recovery. Then, such an approach will be criticized, highlighting that, from a theoretical and general perspective, the technological landscape does not allow a naïve recovery of the past. Rather than copying from the past and imagining impossible continuities, the relationship between technology and humanities points to a different learning path.

Moreover, this vision of history belongs only to a European perspective, and it does not connect the European context to a global approach. ${ }^{17}$

Therefore, historia magistra vitae will not mean just recovering solutions from the past but learning how the past invented new solutions and how legal history may approach discontinuities. The history of legal innovations could become a way to approach future law and politics. Indeed, innovation is a characterizing element of Western culture, much more than a static tradition.

In this broad picture, the European Union is also at a crossroads. On the one side the EU could recover past legal concepts as if it were a museum of Western culture. On the other side, the EU could become a laboratory of a new legal framework. An important part of the challenge is the field in which the European

14 The soft law is observed, recently and from a constitutional point of view, also by Algostino, A, Il diritto proteiforme. Studio sulla trasformazione delle fonti del diritto, Giappichelli, Torino, 2018, pp. 171-197; see the relevance in international contract law, in Vogenauer, S., Common Frame of Reference and UNIDROIT Principles of International Commercial Contracts: Coexistence, Competition, or Overkill of Soft Law?, European Review of Contract Law, no. 6, 2010, p. $143 \mathrm{ff}$.

15 For the topic of ius commune in modern age, also referring to European public law, see Silvestri, G., Verso uno ius commune europeo dei diritti fondamentali, Quaderni costituzionali, no. 1, 2006, pp. 7-24; for the private law, see Zimmermann, R., Usus Hodiernus Pandectarum, in: Schulze, R. (ed.), Europäische Rechts- und Verfassungsgeschichte, Ergebnisse und Perspektiven der Forschung, Duncker \& Humblot, Berlin, 1991, pp. 61-88

16 A critical view of this phenomenon is in Caroni, P., La solitudine dello storico del diritto: appunti sullinerenza di una disciplina altra, Giuffrè, Milano, 2009, p. 176 ff., which speaks openly of neopandettismo

17 Duve, T., Von der Europäischen Rechtsgeschichte zu einer Rechtsgeschichte Europas in globalhistorischer Perspektive, Rechtsgeschichte, no. 20, 2012, pp. 7-18; or recently and diffusely in Duve, T., Global Legal History: Methodological Approach, Oxford Handbooks Online, Oxford, 2017 
institutions will exist. Will the European institutions be on the side of global economic governance or on the side of new constitutionalism?

Some decisions already seem to direct Europe towards the path of globalization, in a sort of "glocal balance", in which the naïve and neo-medieval approach will have some space. ${ }^{18}$

However, in many cases, we are witnessing new regulatory phenomena and new legal frameworks, of which Europe is the main if not the only laboratory in the World. The future is yet to be written. On the path of the new constitutionalism, we will not necessarily find the concepts of the past. Our task will also be to recognize the new forms of law and to participate in this new Kampf ums Recht. ${ }^{19}$

\section{METHODOLOGY}

This contribution aims to adopt the methodological framework offered by the most recent historical thought, which underlines the difficulty of adopting static categories and univocal perspectives and promotes a braided approach with contextual and contrastive views of the same object of study. ${ }^{20}$

First, there is a progressive tendency to adopt different perspectives for the investigation of historical phenomena, in order to deconstruct static and simplified images of the past.

However, the entanglement in legal history and the histoire croisée ${ }^{21}$ are methodologies, as also noted by historians, not sufficiently rooted in the awareness of jurists.

Indeed, "positive law" jurists often make forays into history, frequently without any methodological prudence. It happens for example, when the current legal tools no longer seem usable for the regulation of new phenomena.

18 Algostino, op. cit. note 14, 112

19 Ibid. in the sense of the fight for the constitutionalism more than for the law, but still with reference to Jhering's idealistic use of the expression, von Jhering, R., Der Kampf ums Recht, Manz, Wien, 1872

20 Also in Duve, T., European Legal History - Concepts, Methods, Challenges, in: Id. (ed.), Entanglements in Legal History: Conceptual Approaches, Frankfurt am Main, 2014, pp. 3-25; recently also Duve, T., Global Legal History: Methodological Approach, Oxford Handbooks Online, Oxford, 2017; in the field of legal transfer and transplant, see Foljanty, L., Legal Transfers as Processes of Cultural Translation: On the Consequences of a Metaphor, MPI Research Paper Series, 2015, or Vano, C., Canti per il diritto. In margine alla traduzione di un testo interdisciplinare, in: Fögen, M. T., Il canto della legge, Editorale Scientifica, Napoli, 2012, p. 129 ff.; some significant methodological reflections also in Ead., Della vocazione dei nostri luoghi. Traduzioni e adattamenti nella diffusione internazionale dell'opera di F.C. von Savigny, Historia et ius, no. 10, 2016, pp. 1-16

21 This proposal was strongly supported by Werner, M.; Zimmermann, B., Penser l'histoire croisée: entre empirie et réflexivité, Annales, no. 58, 2003, pp. 5-36 
Therefore, a comparison between historical research methodologies and legal research is important. The effort may indicate to the jurists the possible ways to disengage from the current legal concepts. For this reason, a comparison among methodologies can appear much more productive than a comparison among results.

There is at least one other fundamental factor, well-known to legal historiography: law is only one of the normative dimensions in every social context. Therefore, an understanding of historical problems appears risky and incomplete if there is no awareness of the importance of multi-normativity. ${ }^{22}$

The same considerations, which apply to the past, can apply to the future of law.

From a methodological point of view, the approach aims to highlight the critical issues of a naïve recovery of the past. Nonetheless, the paper intends to contribute theoretically to strengthening a proposal: to open a comparison with the historical methodology to enrich the reflection on the regulation of new technological phenomena and society in the world of the future.

\section{THE FALL OF MODERN LEGAL CONCEPTS}

The literature on the legal concepts crisis is very broad and it is possible to list many examples. This contribution can investigate only a few concepts, with reference to constitutional law in the European legal framework, which is maybe one of the most characteristic elements of modernity as well as the most at-risk area. The direction of future research can be positively influenced by the common interest of other researchers who share the general frame. A deeper analysis could be developed in relation to some of the following fundamental issues.

- Citizenship. In this case a plurality of recipients of the rules replaces the concept of citizen, the only legal entity of modern legal Codification. This varied set of different subjects induces some authors to think of a parallelism with the different social categories (with different statuses) that characterized the whole population in the Middle Ages. ${ }^{23}$ A landscape characterized by the presence of consumers and multinational corporations does not allow for the use of abstract concepts of formal equality. This erosion of citizenship has repercussions for both civil and constitutional law.

22 Duve, T., Was ist ,Multinormativität? - Einführende Bemerkungen, Rechtsgeschichte, no. 25, 2017, pp. 88-101

23 On the return to a society organised into categories and the relationship between citizenship and globalization, see Joerges, C.; Sand, I. J.; Teubner, G. (eds.), Transnational Governance and Constitutionalism, Hart Publishing, Portland, 2004 
- Territory. The link between sovereignty and territory, a progressive result of the Modern Age starting from the Peace of Westphalia, seems to be compromised due to the phenomenon of "deterritorialization". ${ }^{24}$ The main erosion factor of the concept of territory relates to the creation of the digital environment, next to the linked issue of the multilevel governance of different public institutions. ${ }^{25}$

- Sovereignty. This fundamental concept of modern constitutionalism is under strong discussion. The weakening of the concepts of citizenship and territory contributes to the erosion of this concept, occurring from the broadening of local and supranational powers. ${ }^{26}$ The new technologies have a strong impact both because they are in the domain of private companies and because sovereign powers need to use them for legitimacy and to reach consensus. ${ }^{27}$ Some authors speak openly of a crisis or an erosion of the sovereignty. ${ }^{28}$

- Representation. This concept has two problematic aspects: the possible deficit of democratic representation of some political institutions (criticism addressed to the institutions of the European Union); ${ }^{29}$ the attempt to introduce different mechanisms of democracy in parliamentary institutions or instead of them (the side of e-democracy and direct online voting). Both aspects allow reference to be made to pre-modern concepts: forms of legitimacy different from the democratic one; a model of political representation closer to the delegative model of private law (a sort of medieval model of representation). ${ }^{30}$

24 The digital deterritorialization is also observed by Sassen, S., Territory, Authority, Rights: From Medieval to Global Assemblages, Princeton University Press, Princeton, 2008

25 Also in Bache, I.; Bartle, I.; Flinders, M., Multi-level Governance, in: Ansell, C.; Torfing, J. (eds.), Handbook on Theories of Governance, Elgar, Cheltenham, 2016, pp. 486-498

26 This stretching is observed, for example, in Teubner, G., Constitutional Fragments: Societal Constitutionalism and Globalization, OUP, Oxford, 2012, pp. 42-71

27 The impact of technology on sovereignty, Deibert, R. J., The Geopolitics of Internet Control: Censorship, Sovereignty, and Cyberspace, in: Chadwick, A.; Howard, P. N., Routledge handbook of Internet politics, Routledge, Abingdon, 2008, pp. 339-352

28 Ruggeri, A., Prime note per uno studio su crisi della sovranità e crisi della rappresentanza politica, Consulta online, no. 3, 2016, pp. 444-451; or Bin, R., La sovranità nazionale e la sua erosione, in: Pugiotto. A. (ed.), Per una consapevole cultura costituzionale. Lezioni magistrali, Jovene, Napoli, 2013, pp. 369381

29 For the democracy deficit in the EU, see also Grimm, D., The Constitution of European Democracy, OUP, Oxford, 2017, pp. 105-115

30 The concept of delegative models of democracy for e-government, for example, is in Brill, M., Interactive Democracy: New Challenges for Social Choice Theory, in: Laslier, J. F.; Moulin, H.; Sanver, M.; Zwicker, W. (eds.), The Future of Economic Design, Springer, Berlin, 2019, pp. 59-66; on the concept of representation in Italian literature, recently Girelli, F., Il mandato parlamentare e lo spazio della sua libertà, Editoriale Scientifica, Napoli, 2018; see also Luciani, M., Il paradigma della rappresentanza di fronte alla crisi del rappresentato, in: 
- Hierarchy of sources. The disorder on the horizon of the sources is described by some authors as a "law upside down". The power of regulation of privates is also observed as one of the main factors of this issue. ${ }^{31}$ This disorder entails a reflection on the rule of law and the principle of legality. The literature frequently tries to describe this landscape, referring also to the variable "geometry of sources" in the Middle Ages.

In all these fields there are more examples of solutions from the past in the present landscape. As a matter of fact, the jurists often use figures from the past for the regulation of new phenomena of globalization and technologies: the return to lex mercatoria for new markets; a ius commune after the fall of the States; the appeal to the relevant role of the jurists; a return to a big courts era, etc.

The contribution addresses just some misconceptions of this use of legal history. A greater awareness by jurists of the historical methodology could induce more prudence towards the use of the past.

In addition, this relationship between humanities and technologies would also appear productive to enrich the methodology of the law of new technologies, in which entanglement and multi-normativity could become real buzzwords.

Furthermore, the erosion of the legal concepts of modernity cannot be described only as a negative phenomenon. In other words, the crisis can represent an opportunity for a rethinking of legal concepts.

\section{A NEW IUS COMMUNE IN THE EUROPEAN FRAMEWORK?}

A typical question regarding the use of past concepts seems to be that of the ius commune. ${ }^{32}$ References to this concept crowd the legal doctrine in different areas. In private law, a frequent reference is made both as regards common European private law, and in a global context. ${ }^{33}$ In public law, it is meant as commune, that

Zanon, N.; Biondi, F. (eds.), Percorsi e vicende attuali della rappresentanza e della responsabilità politica, Giuffrè, Milano, 2001, pp. $109 \mathrm{ff}$.

31 E. g. the law upside down in Iannuzzi, A., Il diritto capovolto, Editoriale Scientifica, Napoli, 2018; the self-regulation and soft law, in Italian literature are in Sileoni, S., Autori delle proprie regole, CEDAM, Padova, 2011

32 Grossi, op. cit. note 8, p. $39 \mathrm{ff}$.

33 For the European private law, Smits, J. M., The Making of European Private Law: Toward a Ius Commune Europaeum as a Mixed Legal System, Intersentia, Cambridge, 2002, p. 2 ff. 
common basis of fundamental rights, nominated by the international community, or more specifically informed in the European context. ${ }^{34}$

First, it is necessary to highlight what the ius commune in Europe was. ${ }^{35}$ Legal historiography allows the concept of ius commune to be defined as a universal subsidiary law. It deals with a concept initially founded on universal medieval ideology, once linked to the unitary idea of the medieval empire. In the reconstruction by historians, medieval law was therefore described by iura propria (different local rights for each territory) and by a common reservoir, the ius commune, rooted in the tradition of Roman law. However, the validity of this common law and its effectiveness was not identical in time and space. ${ }^{36}$

More specifically, the expression 'ius commune' refers to the result of the doctrinal option that made the "rediscovered Justinian law as the new law of the medieval emperor" and "configured it as the universal ius commune of the respublica Christiana". ${ }^{37}$ The tradition of the Roman law was recovered. The corpus iuris civilis was studied with a new methodology to define a subsidiary law, independent from local urban laws. The ius commune, as a common legal framework, was often enforced thanks to the fall of the barbarian realms and the onset of a new system of public relations (the feudal system). ${ }^{38}$

This common and subsidiary legal ground was gradually weakening due to the emergence of the nation-states, ideally attributable to the Peace of Westphalia. ${ }^{39}$ In other words, national sovereignty and territory connected in such a way as to exclude the general application of a common European law. With the birth of the nation-states, the preconditions of ius commune were lacking, because the empire was gradually eroding and its (true or false) legitimacy in the Roman Empire and

34 An example in von Bogdandy, A.; Hinghofer-Szalkay, S., European Public Law - Lessons from the Concept's Past, MPIL Research Paper, no. 5, 2017, pp. 2 ff. and 23 ff.; see also this use of the concept in von Bogdandy, A., Ius Constitutionale Commune en América Latina: Observations on Transformative Constitutionalism, in: Id. et al. (eds.), Transformative Constitutionalism in Latin America: The Emergence of a New Ius Commune, OUP, Oxford, 2017, p. 27 ff.

35 On the concept of ius commune, Santarelli, U., Il ius commune, frutto maturo dell'esperienza giuridica medievale, in: Greco, T.; Bonsignori, F. (eds.), Un solo mondo, un solo diritto?, Pisa University Press, Pisa, 2012, p. $25 \mathrm{ff}$.

36 Diffusely in Wieacker, F., Privatrechtsgeschichte der Neuzeit, Vandenhoeck \& Ruprecht, Göttingen, 1967, vol. 1 , Chapt. III

37 Cavanna, A., Storia del diritto moderno in Europa, Giuffrè, Milano, 1982, pp. 34-35

38 About the German history and the fall of the regnum Teutonicum, Wieacker, op. cit., note 36, vol. I, Part II, $\$ 6$.

39 Preterossi, G., Un diritto internazionale postmoderno? Il contributo di Martti Koskenniemi tra realismo politico e retorica, Sociologia del diritto, no. 3, 2015, p. 131 ff.; or Koskenniemi, M., Why History of International Law Today?, Rechtsgeschichte, no. 4, 2004, pp. 61-66 
in Roman law no longer found a raison d'etre. A sort of new "Westphalian law", different for each territory and decided by various national authorities, replaced the old ius commune. ${ }^{40}$

Therefore, the ius commune was the result of a cultural operation in a plural political context. Vice versa, with the development of the state in the modern age, the law was gradually brought back to the power of the single states. According to the modern view, "the law would be only a force or a will, which would radiate from the state". ${ }^{41}$ However, the model of modern state law weakened after the liberal state crisis in the last century. With regard to the Italian legal culture, Santi Romano highlighted, at the beginning of the twentieth century, that the state system was not "the only system in the legal world». ${ }^{42} \mathrm{He}$ underlined that, although modernity combined together state and law, there is an inverse process in the contemporary world. According to Romano, "with the discovery of the complexity of law, which stemmed directly from the complexity of society, the victory of the society was sanctioned ${ }^{43}$ In other words, the law survives the erosion of the concept of state and turns back to a multi-model horizon.

For this reason, the crisis of the concepts of modernity once again changes the landscape. This time it happened by eroding the same geopolitical and philosophical assumptions that had weakened the ius commune. ${ }^{44}$ Such a narrative would, therefore, allow the recovery of the concepts of medieval law and, among these, of a new ius commune as a collective and subsidiary reservoir.

In this contest, the concept plays completely different roles. First, it can be used to describe that part of private law common to Western countries, to the global market or, more specifically to Europe. The commonality, in this case, is a precondition of the (European or global) single market, which allows or facilitates the exchanges. The exercise of national sovereignty in the possible imposition of a different law would self-exclude some communities from the market, with all economic consequences.

In the opposite direction, some authors think that there is a core of values and fundamental rights, common to Western states. In typical rhetoric, then, these

40 See also Stolleis, M., Vor Modernes und postmodernes Recht, Quaderni Fiorentini, no. 37, 2008, pp. 543-551

41 Romano, S., L'ordinamento giuridico (1918), Quodlibet, Macerata, 2018, p. 98

42 Ibid., p. 102

43 Grossi, P., L'Europa del diritto, Laterza, Roma-Bari, 2010, p. 222

44 Cassese, A., States: Rise and Decline of the Primary Subjects of the International Community, in: Fassbender, B.; Peters, A. (eds.), The Oxford Handbook of the History of International Law, OUP, Oxford, 2012, p. $50 \mathrm{ff}$. 
different "common" fundamental rights and values limit the possible distorted effects of globalization and the global market. Again in this sense, it is stated that there is an ius publicum europaeum, which characterizes the different continental nations and permeates the European institutions and the other European international organizations. ${ }^{45}$

Another similar but different case present in the doctrine consists of the use of "common goods", a concept that characterized pre-modern property, in an attempt to remove some assets from possible market abuse. ${ }^{46}$

In all these examples, the use of the past often appears to be instrumental. Only certain features of some historical narratives are emphasized. There is nothing wrong with this operation. Nonetheless, it does not seem appropriate to qualify such attempts as recovery; they seem rather an invention of new concepts. In other words, the recourse to the past seems to play overall an instrumental and rhetorical function. ${ }^{47}$

The preconditions of the medieval contest are utterly absent in the contemporary one. In the terminology of historians, "common" is what is not affected by local laws (urban laws, iura propria), an eventual, labile and subsidiary ground. In the contemporary context, "commune" is that nucleus of principles that cannot be attacked by states or by the market. These principles cannot be eroded by the single nations either because it is economically unfavourable or because it can be contrary to a framework of values typical of constitutionalism (and Western ethics). ${ }^{48} \mathrm{In}$ none of the cases does the new ius commune appear to be subsidiary and eventual. Furthermore, the use of these expressions risks feeding simplified narratives of the contemporary world. New technologies are changing the conditions of modernity, starting from a distorting of distances and the concept of territory. Also for this reason, the recovery of concepts from the past can often be erroneous.

45 E. g. the volume von Bogdandy, A.; Cassese S.; Huber, P. M. (eds.), Ius Publicum Europaeum, vol. IV, CF Müller, Heidelberg, 2011

46 On this subject, Clavero, B., El Común y no su doble (a propósito de Pasado y Presente de los comunales y de lo comunitario), Quaderni Fiorentini, no. 31, 2008, p. 899 ff.; in the Italian doctrine, Lucarelli, A., La democrazia dei beni comuni: Nuove frontiere del diritto pubblico, Laterza, Roma-Bari, 2013; see also Somma, A., Democrazia economica e diritto privato. Contributo alla riflessione sui beni comuni, Materiali per una storia della cultura giuridica, no. 2, 2011, p. 461 ff.; or the pamphlet of Mattei, U., Beni comuni: un manifesto, Laterza, Roma-Bari, 2012

47 About this question, Stolleis, M., Traditions and Changes and the Role of Legal History, Giornale di storia costituzionale, no. 30, 2015, pp. 11-16

48 von Bogdandy, A.; Hinghofer-Szalkay, S., European Public Law - Lessons from the Concept's Past, MPIL Research Paper, No. 5, 2017, pp. 2 ff. and 23 ff.; again Silvestri, op. cit., note 15, p. 7 ff. 
Briefly, this approach can be summarized in a series of inequalities: the European Union is not the Holy Roman Empire; ${ }^{49}$ the new global market does not have a lex mercatoria like the medieval one; ${ }^{50}$ environmental problems cannot be solved simply by the use of common goods of medieval law $;{ }^{51}$ the new constitutionalism is not merely a new ius publicum Europaeum; contract law is not a sort of new Roman law, ${ }^{52}$ etc.

None of these sentences is more valid or more erroneous than their opposites. However, it should be emphasized that good practices and dangerous abuses exist in the use of the past. On the one hand, we can adopt models of historical interpretation to explain new legal and political concepts. In this operation, the risk is to simplify the narration of the present by placing critical characteristic elements. On the other hand, we observe that historiography has a very prudent methodology, which avoids adopting static and abstract concepts in the explanation of complex phenomena.

For this reason, a close comparison with the historians' methodology can allow for greater flexibility in the analysis of future landscapes. The first possible result would consist of avoiding errors deriving from the abuse of concepts suitable to represent a reality but inadequate to another context. In the long run, however, this exercise can allow the positive jurist to distance himself from the conceptual schemes of the present.

Indeed, the new landscape places the jurist in a new position with strong analogies with the past. Then, we can hypothesize a «revival of remote legal civilizations», which is a "useful and, at the same time, distorting thought», because there is a high risk of overlooking the specific features of the current context. ${ }^{53}$ The analogies with the past lead us to consider as European unitary elements a common science, a standard legal method, and a framework of shared values. The challenge of building a common science arises in the current context similarly to the past, when «the historical Ius Publicum Europaeum was founded on an integrated sci-

49 In the legal-historical debate, see Cassese, S., Che tipo di potere pubblico è l'Unione Europea?, Quaderni Fiorentini, no. 31, 2008, p. $141 \mathrm{ff}$.

50 A review of the debate in Gialdroni, S., Gerald Malynes e la questione della lex mercatoria, Zeitschrift Savigny Stiftung, Germ. Abt., no. 126, 2009, p. 38 ff.

51 On this concept, see diffusely Kempshall, M. S., The Common Good in Late Medieval Political Thought, OUP, Oxford, 1999

52 For example, this approach is in Zimmermann, R., Das römisch-kanonische ius commune als Grundlage europäischer Rechtseinheit, Juristenzeitung, no. 1, 1992, pp. 8-20

53 Ibid., 255 
entific culture». ${ }^{54}$ In the current context, the strength of the Roman law tradition returns to fascinate private law scholars whereas a set of common values attract the public and constitutional law scholars. The interaction between these two trends leads to a new form of ius commune and a new secularized form of respublica christiana. ${ }^{55}$ The object of the new common science would no longer be the private law, as defined by the nineteenth-century bourgeoisie. The modern common science should focus on a European, interdisciplinary, and cross-national administrative law, thanks to the convergence of the private law's methodology with the fundamental values of constitutionalism.

The scientific option for a new European ius commune is not a mere recovery of a past dream. The analogy uses references to the past without overlooking the characteristics of the present. However, this scientific option often insists on strong continuity with an idealized past. Furthermore, this option is based on conditions that may not arise in the future.

The option of a modern common science rises some critical issues.

First, it could be optimistic and unfeasible to build a common science independent of local contexts.

Second, the success of the option depends on the existence of a European community of values rather than on a mere commercial and economic space.

Third, the option highlights the pivotal role of jurists, as a class capable of mediation between society and law, although democratic issues rely on the pressure of political representative institutions. Thus, the attempt to save the values of constitutionalism with the use of a law produced by courts and doctrine could fail because it neglects the role of representative democracy in the affirmation of fundamental rights.

\section{POSSIBLE FUTURE RESULTS AND IMPLICATIONS: INTERDISCIPLINARY REFLECTION BACKGROUND}

The research path aims to recover the results of the most recent historiography, that demonstrate the partial groundlessness of the images of the past built by modernity. As a matter of fact, some views of the past adopted in legal culture seem to be an artificial construction, in which historical truth, myths and misunderstandings are mixed.

\footnotetext{
54 See also Bogdandy, A., Il diritto amministrativo nello spazio giuridico europeo: cosa cambia, cosa rimane, in: Id.; Cassese, S.; Schiera, P., Lo Stato e il suo diritto, Il Mulino, Bologna, 2010, p. 135

55 On this topic, see Schmitt, C., Der Nomos der Erde, Duncker \& Humboldt, Berlin, 1974, Chapt. 2
} 
These misunderstandings can offer a wrong image of the past and do not help to build legal models and solutions for the future, because they tend to simplify the interpretation of the phenomena. A good example is certainly the one offered using the concept of ius commune, but possible research in other directions could achieve similar results.

The future analysis could show that literature, almost unanimously, converges in attributing a decisive role in the collapse of the categories of modernity to new technologies and the impact of disruptive innovation in progress. This perspective, therefore, would not permit a simple and naïve recovery of the past, because the landscape is crowded with new protagonists and new problems.

Any search for solutions for the future in the Beispielsammlung of history would not be the right way of describing the relationship between Werden and Sein. Another relationship is instead possible: the legal history is a discipline in which scholars try to distance themselves from their object of research. Legal historians study law, without being limited by its static concepts. The research of legal frames for regulating new technologies could therefore learn from historical methodology, making history of our own present and moving away from current legal concepts. The question this paper would address is: in what relationship do legal historians and jurists of the future place themselves?

Within the framework of this research path it is possible, once the in-depth context has been chosen, to begin a collaboration with other researchers. In the long run it is also possible to imagine that historians and jurists of new technologies can collaborate on a common ground. The paper aims to contribute to opening an interdisciplinary field of reflection in which legal historians and jurists participate in the debate on the regulation of new technologies.

The need for a connection between technology and humanities is frequently affirmed. The plot of possible links between these two worlds is full of pitfalls. The contribution addresses the theoretical and methodological aspects of this relationship, highlighting the risks of naïve uses of the past and the advantages of a methodologically founded comparison.

For these reasons, the implications on the methodological level are central in this research path, with reference to a comparison between legal theory and legal history. 


\section{REFERENCES}

\section{BOOKS AND ARTICLES}

1. Algostino, A., Il diritto proteiforme. Studio sulla trasformazione delle fonti del diritto, Giappichelli, Torino, 2018

2. Bache, I.; Bartle, I.; Flinders, M., Multi-level Governance, in: Ansell, C.; Torfing, J. (eds.), Handbook on Theories of Governance, Elgar, Cheltenham, 2016

3. Berger, K. P., The Creeping Codification of the New Lex Mercatoria, Kluwer, Köln, 2010

4. Bin, R., La sovranità nazionale e la sua erosione, in: Pugiotto. A. (ed.), Per una consapevole cultura costituzionale. Lezioni magistrali, Jovene, Napoli, 2013

5. von Bogdandy, A.; Cassese, S.; Schiera, P., Lo Stato e il suo diritto, Il Mulino, Bologna, 2010

6. von Bogdandy, A.; Cassese S.; Huber, P. M. (eds.), Ius Publicum Europaeum, vol. IV, CF Müller, Heidelberg, 2011

7. von Bogdandy, A.; Hinghofer-Szalkay, S., European Public Law - Lessons from the Concept's Past, MPIL Research Paper, 2017

8. von Bogdandy, A., Ius Constitutionale Commune en América Latina: Observations on Transformative Constitutionalism, in: Id. et al. (eds.), Transformative Constitutionalism in Latin America: The Emergence of a New Ius Commune, OUP, Oxford, 2017

9. Brill, M., Interactive Democracy: New Challenges for Social Choice Theory, in: Laslier J. F.; Moulin, H.; Sanver, M.; Zwicker, W. (eds.), The Future of Economic Design, Springer, Berlin, 2019

10. Caroni, P., La solitudine dello storico del diritto: appunti sull'inerenza di una disciplina altra, Giuffrè, Milano, 2009

11. Cassese, S., La crisi dello stato, Laterza, Roma-Bari, 2002

12. Cassese, S., Che tipo di potere pubblico è l'Unione Europea?, Quaderni Fiorentini, 2008

13. Cassese, A., States: Rise and Decline of the Primary Subjects of the International Community, in: Fassbender, B.; Peters, A. (eds.), The Oxford Handbook of the History of International Law, OUP, Oxford, 2012

14. Cavanna, A., Storia del diritto moderno in Europa, Giuffrè, Milano, 1982

15. Clavero, B., El Común y no su doble (a propósito de Pasado y Presente de los comunales y de lo comunitario), Quaderni Fiorentini, 2008

16. Costa, P., Cittadinanza, Laterza, Roma-Bari, 2014

17. Costa, P., Democrazia e conflitti, Giornale di storia costituzionale, 2019

18. Deibert, R. J., The Geopolitics of Internet Control: Censorship, Sovereignty, and Cyberspace, in: Chadwick, A.; Howard, P. N., Routledge Handbook of Internet Politics, Routledge, Abingdon, 2008

19. Duve, T., Von der Europäischen Rechtsgeschichte zu einer Rechtsgeschichte Europas in globalhistorischer Perspektive, Rechtsgeschichte, 2012

20. Duve, T., European Legal History - Concepts, Methods, Challenges, in: Id. (ed.), Entanglements in Legal History: Conceptual Approaches, Frankfurt am Main, 2014

21. Duve, T., Was ist ,Multinormativität?? - Einführende Bemerkungen, Rechtsgeschichte, 2017 
22. Duve, T., Global Legal History: Methodological Approach, Oxford Handbooks Online, Oxford, 2017

23. Foljanty, L., Legal Transfers as Processes of Cultural Translation: On the Consequences of a Metaphor, MPI Research Paper Series, 2015

24. Friedrichs, J., The Meaning of New Medievalism, European Journal of International Relations, 2001

25. Galgano, F., Lex mercatoria, Il Mulino, Bologna, 2001

26. Gamble, A., Regional Blocs, World Order and the New Medievalism, in: Telov, M. (ed.), European Union and New Regionalism, Ashgate, Aldershot, 2001

27. Gialdroni, S., Gerald Malynes e la questione della lex mercatoria, Zeitschrift Savigny Stiftung, 2009

28. Girelli, F., Il mandato parlamentare e lo spazio della sua libertà, Editoriale Scientifica, Napoli, 2018

29. Grimm, D., The Constitution of European Democracy, OUP, Oxford, 2017

30. Grossi, P., Unità giuridica europea: un medioevo prossimo futuro?, Quaderni fiorentini, 2002

31. Grossi, P., La proprietà e le proprietà nell'officina dello storico, Editoriale Scientifica, Napoli, 2006

32. Habermas, J., Citizenship and National Identity: Some Reflections on the Future of Europe, Praxis International, 1992

33. Haferkamp, H.-P., Die Historische Rechtsschule, Klostermann, Frankfurt am Main, 2018

34. Iannuzzi, A., Il diritto capovolto, Editoriale Scientifica, Napoli, 2018

35. Irti, N., Un diritto incalcolabile, Giappichelli, Torino, 2016

36. von Jhering, R., Der Kampf ums Recht, Manz, Wien, 1872

37. Joerges, C.; Sand, I. J.; Teubner, G. (eds.), Transnational Governance and Constitutionalism, Hart Publishing, Portland, 2004

38. Kempshall, M. S., The Common Good in Late Medieval Political Thought, OUP, Oxford, 1999

39. Koskenniemi, M., Why History of International Law Today?, Rechtsgeschichte, 2004

40. Kobrin, S. J., Neomedievalism and the Postmodern Digital World Economy, in Prakash, A.; Hart, J. A. (eds.), Globalization and Governance, Routledge, London, 1999

41. Lucarelli, A., La democrazia dei beni comuni: Nuove frontiere del diritto pubblico, Laterza, Roma-Bari, 2013

42. Luciani, M., L'antisovrano e la crisi delle costituzioni, Rivista di diritto costituzionale, 1996

43. Luciani, M., Il paradigma della rappresentanza di fronte alla crisi del rappresentato, in: Zanon, N.; Biondi, F. (eds.), Percorsi e vicende attuali della rappresentanza e della responsabilità politica, Giuffrè, Milano, 2001

44. Mattei, U., Beni comuni: un manifesto, Laterza, Roma-Bari, 2012

45. Petit, C., Historia del derecho mercantile, Marcial Pons, Madrid, 2016

46. Piergiovanni, V. (ed.), From Lex Mercatoria to Commercial Law, Duncker \& Humblot, Berlin, 2005 
47. Preterossi, G., Tramonto del diritto moderno?, in: Bazzicalupo, L., Esposito, R. (eds.), Politica della vita. Sovranità, biopotere, diritti, Laterza, Roma-Bari, 2003

48. Preterossi, G., Un diritto internazionale postmoderno? Il contributo di Martti Koskenniemi tra realismo politico e retorica, Sociologia del diritto, 2015

49. Romano, S., L'ordinamento giuridico (1918), Quodlibet, Macerata, 2018

50. Rückert, J., Savigny Studien, Klostermann, Frankfurt am Main, 2011, or Id. (ed.), Idealismus, Jurisprudenz und Politik bei Friedrich Carl von Savigny, Klostermann, Frankfurt am Main 2019

51. Ruggeri, A., Prime note per uno studio su crisi della sovranità e crisi della rappresentanza politica, Consulta online, no. 3, 2016

52. Santarelli, U., Il ius commune, frutto maturo dell'esperienza giuridica medievale, in: Greco, T.; Bonsignori, F. (eds.), Un solo mondo, un solo diritto?, Pisa University Press, Pisa, 2012

53. Sassen, S., Territory, Authority, Rights: From Medieval to Global Assemblages, Princeton University Press, Princeton, 2008.

54. von Savigny, F. C., Über Den Zweck dieser Zeitschrift, Zeitschrift für geschichtliche Rechtswissenschaft, 1815

55. Sileoni, S., Autori delle proprie regole, CEDAM, Padova, 2011

56. Silvestri, G., Verso uno ius commune europeo dei diritti fondamentali, Quaderni costituzionali, 2006

57. Smits, J. M., The Making of European Private Law: Toward a Ius Commune Europaeum as a Mixed Legal System, Intersentia, Cambridge, 2002

58. Somma, A., Democrazia economica e diritto privato. Contributo alla riflessione sui beni comuni, Materiali per una storia della cultura giuridica, 2011

59. Stolleis, M., Vor Modernes und postmodernes Recht, Quaderni Fiorentini, 2008

60. Stolleis, M., Traditions and Changes and the Role of Legal History, Giornale di storia costituzionale, no. 30, 2015

61. Teubner, G., Constitutional Fragments: Societal Constitutionalism and Globalization, OUP, Oxford, 2012

62. Vacca, R., Il medioevo prossimo venturo, Mondadori, Milano 1973

63. Vano, C., Canti per il diritto. In margine alla traduzione di un testo interdisciplinare, in: Fögen, M. T., Il canto della legge, Editorale Scientifica, Napoli 2012

64. Vano, C., Della vocazione dei nostri luoghi. Traduzioni e adattamenti nella diffusione internazionale dell'opera di F.C. von Savigny, Historia et ius, 2016

65. Vogenauer, S., Common Frame of Reference and UNIDROIT Principles of International Commercial Contracts: Coexistence, Competition, or Overkill of Soft Law?, European Review of Contract Law, 2010

66. Werner, M.; Zimmermann, B., Penser l'histoire croisée: entre empirie et réflexivité, Annales, 2003

67. Wieacker, F., Privatrechtsgeschichte der Neuzeit, Vandenhoeck \& Ruprecht, Göttingen, 1967 
68. Zimmermann, R., Usus Hodiernus Pandectarum, in: Schulze, R., (ed.), Europäische Rechtsund Verfassungsgeschichte, Ergebnisse und Perspektiven der Forschung, Duncker \& Humblot, Berlin, 1991

69. Zimmermann, R., Das römisch-kanonische ius commune als Grundlage europäischer Rechtseinheit, Juristenzeitung, 1992 